\title{
Hubungan Resistensi Insulin dengan Gambaran Klinis Sindrom Ovarium Polikistik
}

\author{
Meliza Wahyuni ${ }^{1}$, Eva Decroli ${ }^{2}$, Putri Sri Lasmini ${ }^{3}$
}

\begin{abstract}
Abstrak
Sindrom Ovarium Polikistik (SOPK) merupakan kelainan endokrin dan metabolik pada wanita usia reproduksi. SOPK merupakan kumpulan gejala dari amenore, oligomenore, infertilitas, obesitas, hirsutisme, acne, alopesia, dan akantosis nigrikan. Resistensi insulin diyakini sebagai salah satu penyebab tersering dari SOPK melalui berbagai mekanisme. Tujuan penelitian ini adalah untuk mengetahui hubungan resistensi insulin dengan gambaran klinis SOPK. Penelitian ini dilakukan pada pasien SOPK dengan menggunakan studi cross sectional dengan pendekatan retrospektif, yaitu mengumpulkan kejadian masa lalu dari tahun 2009 - 2011 , jumlah sampel 105 orang. Analisis statistik yang digunakan adalah uji chi-square. Hasil penelitian didapatkan $33,3 \%$ penderita SOPK mengalami resistensi insulin. Berdasarkan gambaran klinis 35,23\% amenore, 64,77\% oligomenore, $72,04 \%$ infertilitas, $50,5 \%$ obesitas, $0,95 \%$ hirsutisme, acne $20 \%$, alopesia dan akantosis nigrikan 0\%. Dari 33,3\% SOPK dengan resistensi insulin 40\% amenore, 60\% oligomenore, $71,9 \%$ infertilitas, $77,14 \%$ obesitas, dan $0 \%$ hirsutisme. Berdasarkan hasil uji statistik ditemukan hubungan bermakna antara resistensi insulin dengan obesitas $(p<0,05)$ dan tidak ditemukan hubungan bermakna antara resistensi insulin dengan infertilitas, hirsutisme, dan acne ( $p>0,05)$.
\end{abstract}

Kata Kunci: SOPK, resistensi insulin, gambaran klinis

\begin{abstract}
Polycystic Ovary Syndrome (PCOS) is an endocrine and metabolic disorders that is common in reproductive-aged women. PCOS is a group of symptoms, such as amenorrhea, oligomenorrhea, infertility, obesity, hirsutism, acne, alopecia, and achanthosis nigricans. Insulin resistance is believed to be one of the most common causes of PCOS through a various mechanisms. The objective of this study was to find out the relationship between insulin resistance and clinical manifestation of PCOS. This research was done in patients with PCOS using cross sectional study with retrospective approach. Data was collected from 2009-2011, with the sample of 105 patients. This research used statistical analysis, that was chi square test. This research found that $33.3 \%$ patients of PCOS have insulin resistance. Based on clinical manifestation found that $35.23 \%$ amenorrhea, $64.77 \%$ oligomenorrhea, $72.04 \%$ infertility, 50.5\% obesity, 0.95\% hirsutism, 20\% acne, 0\% alopecia and achanthosis nigricans. From 33.3\% PCOS with insulin resistance, 40\% amenorrhea, 60\% oligomenorrhea, $71.9 \%$ infertility, $77.14 \%$ obesity, and $0 \%$ hirsutism. The results showed that there is a significant relationship between insulin resistance and obesity $(p<0.05)$ and no significant reslationship between insulin resistance and infertility, hirsutism, and acne ( $p>0.05)$.
\end{abstract}

Keyword: PCOS, insulin resistance, clinical manifestation

Affiliasi Penulis: 1. Pendidikan Dokter FK UNAND (Fakultas Kedokteran Universitas Andalas Padang), 2. Bagian IImu Penyakit Dalam FK UNAND/ RSUP DR. M. Djamil Padang, 3.
Bagian Obstetri dan Ginekologi FK UNAND/ RSUP DR. M. Djamil Padang.

Korespondensi: Meliza Wahyuni, E-mail:

melizaelf91@gmail.com, Telp: 082284626414 


\section{PENDAHULUAN}

Sindrom ovarium polikistik merupakan kumpulan gejala dari amenore, oligomenore, infertilitas, hirsutisme, dan obesitas. ${ }^{1,2}$ Studi epidemiologi menunjukkan bahwa 5\% - 10\% wanita usia reproduksi menderita SOPK. ${ }^{3}$

Prevalensi gambaran klinis SOPK sangat beragam. Pada tahun 1989, Franks dalam penelitiannya melaporkan dari 300 wanita SOPK $52 \%$ amenore, $28 \%$ oligomenore, $64 \%$ hirsutisme, $35 \%$ mengalami obesitas, $27 \%$ dengan acne, $3 \%$ alopecia, kurang dari $1 \%$ dengan tanda-tanda akantosis nigrikan, dan $42 \%$ mengalami infertilitas. $^{4}$

Penyebab kausal dari SOPK sampai saat ini tidak diketahui dengan pasti. Resistensi insulin diyakini sebagai principal underlying etiologic factor. Hal ini juga dibuktikan dengan tingginya angka kejadian resistensi insulin pada penderita SOPK. ${ }^{4-6}$

Resistensi insulin akan menimbulkan keadaan hiperinsulinemia sebagai reaksi kompensasi insensitivitas insulin. Tingginya kadar insulin akan merangsang produksi androgen ovarium dengan berbagai mekanisme. Hiperinsulinemia akan menghambat sekresi hepar dalam menghasilkan Insulin like Growth Factor Binding Protein-I (IGFBP-I) dan meningkatkan Insulin like Growth Factor-I (IGF-I). Kelebihan insulin akan diikat oleh IGF-I yang bekerja pada sel teka untuk meningkatkan kadar LH. Insulin juga akan mengaktifasi jalur fosforilasi serin yang bisa meningkatkan aktivitas $\mathrm{P} 450 \mathrm{c} 17$ pada ovarium dan adrenal yang akan menstimulasi sintesis androgen. ${ }^{4}$

Insulin juga menekan kadar Sex Hormone Binding Globulin (SHBG) sehingga kadar androgen bebas meningkat. Tingginya kadar androgen akan mengganggu sistem aromatase di dalam sel granulosa sehingga memicu terjadinya atresia folikel lebih dini. ${ }^{4,5}$

Teori ini dibuktikan dengan penelitian yang dilakukan di RS. Cipto Mangunkusumo dengan hasil $75 \%$ penderita SOPK mengalami resistensi insulin. $^{7}$ Hal ini sejalan dengan penelitian
Rusnasari di RSIA Anugerah Semarang pada tahun 2005 yang menyimpulkan bahwa 82,9\% pasien SOPK mengalami resistensi insulin. ${ }^{8}$

Resistensi insulin dapat diukur dengan berbagai metode. Berdasarkan American Diabetes Association, teknik klem euglikemik merupakan baku emas/gold standar pengukuran sensitivitas jaringan terhadap insulin. Teknik ini tidak praktis digunakan untuk klinis sehari-hari, ${ }^{9}$ sehingga digunakan metode yang lebih sederhana dan mempunyai korelasi tinggi dengan klem euglikemik dalam menilai sensitivitas insulin., yaitu HOMA-IR (Homeostasis Model Assesment Insulin Resistance). .,9 $^{5}$

Tujuan penelitian ini adalah untuk mengetahui hubungan resistensi insulin dengan gambaran klinis SOPK.

\section{METODE}

Metode penelitian yang digunakan adalah cross sectional dengan pendekatan retrospektif. Penelitian dilakukan di Apotek Sinar Padang pada bulan Agustus - Desember 2012. Subjek penelitian diambil dari data rekam medik wanita SOPK yang memenuhi kriteria inklusi dan eksklusi yang datang ke klinik Apotek Sinar Padang pada tahun 2009 - 2011.

HASIL

\section{Karakteristik Penelitian}

Tabel 1. Distribusi karakteristik subjek penelitian $(n=105)$

\begin{tabular}{rcc}
\hline \multirow{2}{*}{ Karakteristik } & \multicolumn{2}{c}{ SOPK } \\
\cline { 2 - 3 } & $\mathbf{f}$ & $\%$ \\
\hline Umur (tahun) : & 8 & 7,6 \\
\hline$-\quad \leq 20$ & 78 & 74,3 \\
$-\quad 31-30$ & 18 & 17,1 \\
\multicolumn{1}{c}{$>\quad 40$} & 1 & 1 \\
\hline Jumlah & 105 & 100 \\
\hline Status Perkawinan: & & \\
\hline Belum Kawin & 12 & 11,4 \\
Kawin/ Menikah & 93 & 88,6 \\
\hline Jumlah & 105 & 100 \\
\hline
\end{tabular}


Berdasarkan Tabel 1 dapat dilihat bahwa subjek penelitian terbanyak terdapat pada kelompok umur 21 - 30 tahun yang berjumlah 78 orang $(74,3 \%)$, dan status perkawinan terbanyak adalah menikah/kawin sebanyak 93 orang $(88,6 \%)$.

\section{Resistensi Insulin}

Resistensi insulin didapat dari hasil perhitungan HOMA-IR, yaitu perkalian hasil gula darah puasa dan insulin puasa dibagi dengan 22,5 . Subjek penelitian dikatakan resistensi insulin jika nilainya $>2,5$.

Tabel 2. Distribusi frekuensi pemeriksaan gula darah dan insulin subjek penelitian

\begin{tabular}{lcllll}
\hline Variabel & $\mathbf{f}$ & Mean & SD & Max & Min \\
\hline GDP & 105 & 95,98 & 1,007 & 130 & 76 \\
GD2PP & 104 & 128,20 & 3,34 & 245 & 58 \\
IP & 105 & 14,66 & 2,89 & 271 & 2 \\
I2P & 104 & 78,47 & 7,42 & 300 & 1,1 \\
\hline HOMA-IR & 105 & 3,65 & 7,99 & 76,28 & 0,4
\end{tabular}

Berdasarkan Tabel 2 dapat dilihat bahwa rata-rata gula darah puasa pada subjek penelitian adalah 95,98 $\pm 1,007 \mathrm{mg} / \mathrm{dl}$ dan rata-rata gula darah 2 jam post prandial adalah 128,20 $\pm 3,43$ $\mathrm{mg} / \mathrm{dl}$. Pada pemeriksaan insulin puasa didapatkan rata-rata $14,66 \pm 2,89 \mu \mathrm{U} / \mathrm{ml}$ dan ratarata insulin 2 jam post prandial adalah 78,47 \pm $7,42 \mu \mathrm{U} / \mathrm{ml}$. Sementara itu, dari hasil perhitungan HOMA-IR didapatkan rata-rata 3,65 $\pm 7,99$.

Hasil perhitungan HOMA-IR, maka subjek penelitian dikelompokkan menjadi Resistensi Insulin (IR) dan Non-Resistensi Insulin (non-IR). Dari hasil penelitian didapatkan dari 105 orang subjek penelitian didapatkan 35 orang $(33,3 \%)$ dengan IR, dan 70 orang $(66,7 \%)$ non-IR.

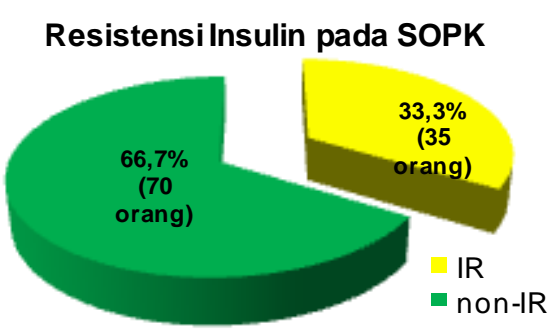

Gambar 1. Gambaran resistensi insulin pada SOPK

\section{Gambaran Klinis SOPK}

Gambaran klinis SOPK terdiri dari amenore/oligomenore, infertilitas, obesitas, hirsustisme, acne, alopecia, dan akantosis nigrikans.

Tabel 3. Distribusi frekuensi gambaran klinis SOPK

\begin{tabular}{lcccc}
\hline \multirow{2}{*}{ Variabel } & \multicolumn{2}{c}{ Ya (+) } & \multicolumn{2}{c}{ Tidak (-) } \\
\cline { 2 - 5 } & $\mathbf{f}$ & $\%$ & $\mathbf{f}$ & $\%$ \\
\hline Amenore/ & 100 & 100 & 0 & 0 \\
Oligomenore & & & & \\
Infertilitas & 67 & 72,04 & 26 & 27,96 \\
Obesitas & 53 & 50,5 & 52 & 49,5 \\
Hirsustisme & 1 & 0,95 & 104 & 99,05 \\
Acne & 21 & 20 & 84 & 80 \\
Alopecia & 0 & 0 & 0 & 0 \\
Akantosis Nigrikan & 0 & 0 & 0 & 0 \\
\hline
\end{tabular}

Tabel 4. Distribusi frekuensi amenore/oligomenore subjek penelitian

\begin{tabular}{ccccccc}
\hline \multirow{2}{*}{ Variabel } & \multicolumn{3}{c}{ Resistensi Insulin } & \multicolumn{2}{c}{ Total } \\
\cline { 2 - 5 } & \multicolumn{2}{c}{ Ya (+) } & \multicolumn{2}{c}{ Tidak (-) } & \multicolumn{2}{c}{} \\
\cline { 2 - 6 } & $\mathbf{F}$ & $\%$ & $\mathbf{F}$ & $\%$ & $\mathbf{F}$ & $\%$ \\
\hline Amenore & 14 & 40 & 23 & 32,85 & 37 & 35,23 \\
Oligomenore & 21 & 60 & 47 & 67,15 & 68 & 64,77 \\
\hline Total & 35 & 100 & 70 & 100 & 105 & 100 \\
\hline
\end{tabular}


Berdasarkan Tabel 3 dapat dilihat bahwa semua subjek penelitian mengalami amenore/ oligomenore, yaitu 105 orang (100\%). Sementara itu, pada tabel 4 dapat dilihat bahwa pada subjek penelitian terdapat 37 orang $(35,23 \%)$ kelompok amenore dan 68 orang (64,77\%) kelompok oligomenore. Jika dikelompokkan berdasarkan resistensi insulin, pada kelompok amenore 14 orang $(40 \%)$ diantaranya mengalami resistensi insulin dan 21 orang $(60 \%)$ mengalami oligomenore.

Gambaran klinis infertilitas didapatkan dari subjek penelitian yang sudah menikah/ kawin, yaitu sebanyak 93 orang. Dari hasil penelitian tersebut didapatkan 67 orang $(72,04 \%)$ datang dengan infertilitas dan sisanya 26 orang $(27,96 \%)$ tidak mengalami infetilitas.
Pada Tabel 3 juga dapat di-simpulkan bahwa penderita SOPK yang mengalami obesitas sebanyak 53 orang $(50,5 \%)$ dan sisanya 52 orang (49,5\%) non-obese. Gambaran klinis hirsutisme jarang ditemukan. Pada subjek penelitian ditemukan 1 orang (0,95\%) dengan hirsutisme dan sisanya 104 orang $(99,05 \%)$ tidak mengalami hirsutisme. Berdasarkan hasil penelitian didapatkan bahwa pada subjek penelitian yang didiagnosa SOPK mengalami acne/ jerawat sebanyak 21 orang (20\%) dan sisanya 84 orang $(80 \%)$ tidak mengalami gejala klinis acne. Sementara itu, pada subjek penelitian tidak ditemukan gambaran klinis alopecia dan akantosis nigrikan. -infertilitas

non-infertilitas

Gambar 2. Gambaran infertilitas pada SOPK

\section{Hubungan Resistensi Insulin dengan Gambaran Klinis SOPK}

Tabel 5. Hubungan resistensi insulin dengan infertilitas dan obesitas pada SOPK

\begin{tabular}{|c|c|c|c|c|c|c|c|c|c|c|c|c|c|c|}
\hline \multirow{3}{*}{ IR } & \multicolumn{4}{|c|}{ Infertilitas } & \multirow{2}{*}{\multicolumn{2}{|c|}{ Total }} & \multirow{3}{*}{$\begin{array}{c}\mathrm{p} \\
\text { chi- } \\
\text { square }\end{array}$} & \multicolumn{4}{|c|}{ Obesitas } & \multirow{2}{*}{\multicolumn{2}{|c|}{ Total }} & \multirow{3}{*}{$\begin{array}{l}\quad \mathrm{p} \\
\text { chi- } \\
\text { square }\end{array}$} \\
\hline & \multicolumn{2}{|c|}{$\mathrm{Ya}$} & \multicolumn{2}{|c|}{ Tidak } & & & & \multicolumn{2}{|c|}{ ya } & \multicolumn{2}{|c|}{ tidak } & & & \\
\hline & $f$ & $\%$ & $f$ & $\%$ & $f$ & $\%$ & & $F$ & $\%$ & $f$ & $\%$ & $f$ & $\%$ & \\
\hline $\mathrm{Ya}(+)$ & 23 & 71,9 & 9 & 28,1 & 32 & 100 & 100 & 27 & 77,14 & 8 & 22,86 & 35 & 100 & 000 \\
\hline Tidak (-) & 44 & 72,13 & 17 & 27,87 & 61 & 100 & & 26 & 37,14 & 44 & 62,86 & 70 & 100 & \\
\hline Total & 67 & & 25 & & 93 & & & 53 & & 70 & & 105 & & \\
\hline
\end{tabular}

Tabel 6.' Hubungan resistensi insulin dengan hirsustisme dan acne pada SOPK

\begin{tabular}{|c|c|c|c|c|c|c|c|c|c|c|c|c|c|c|}
\hline \multirow{3}{*}{ IR } & \multicolumn{4}{|c|}{ Hirsustisme } & \multirow{2}{*}{\multicolumn{2}{|c|}{ Total }} & \multirow{3}{*}{$\begin{array}{c}\mathrm{p} \\
\text { fisher } \\
\text { exact }\end{array}$} & \multicolumn{4}{|c|}{ Acne } & \multirow{2}{*}{\multicolumn{2}{|c|}{ Total }} & \multirow{3}{*}{$\begin{array}{c}\mathrm{p} \\
\text { chi- } \\
\text { square }\end{array}$} \\
\hline & \multicolumn{2}{|c|}{$\overline{Y a}$} & \multicolumn{2}{|c|}{ Tidak } & & & & \multicolumn{2}{|c|}{ ya } & \multicolumn{2}{|c|}{ tidak } & & & \\
\hline & $\mathrm{F}$ & $\%$ & $f$ & $\%$ & $f$ & $\%$ & & $\mathrm{~F}$ & $\%$ & $f$ & $\%$ & $f$ & $\%$ & \\
\hline $\mathrm{Ya}(+)$ & 0 & 0 & 35 & 100 & 35 & 100 & 0667 & 7 & 20 & 28 & 80 & 35 & 100 & 100 \\
\hline Tidak (-) & 1 & 1,42 & 69 & 98,58 & 104 & 100 & $0,06 /$ & 14 & 20 & 56 & 80 & 70 & 100 & 1,00 \\
\hline Total & 1 & & 70 & & 105 & & & 21 & & 84 & & 105 & & \\
\hline
\end{tabular}


Berdasarkan Tabel 5 dapat disimpulkan bahwa pada kelompok SOPK dengan IR (+) adalah 23 orang $(71,9 \%)$ dari 32 orang yang mengalami infertilitas. Sementara itu, angka kejadian infertilitas pada kelompok SOPK dengan IR (-) adalah 44 orang $(72,13 \%)$ dari 61 orang. Berdasarkan hasil uji statistik chi square, tidak ditemukan hubungan yang bermakna antara infertilitas dengan resistensi insulin pada sindrom ovarium polikistik (SOPK) dengan $p$ value 1,00 .

Hubungan resistensi insulin dengan obesitas pada SOPK juga dapat dilihat pada tabel 5 , dimana dapat disimpulkan bahwa pada kelompok SOPK dengan IR (+) dari 35 orang, 77,14\% (27 orang) diantaranya mengalami obesitas. Sementara itu, pada kelompok SOPK dengan IR (-) gambaran klinis obesitas terdapat sebanyak 26 orang $(37,14 \%)$ dari 70 orang. Berdasarkan hasil uji statistik chi square, dapat disimpulkan adanya hubungan bermakna antara obesitas dengan resistensi insulin pada sindrom ovarium polikistik, dengan $p$ value 0,000 ( $p$ value $<0,05$ ).

Pada Tabel 6 dapat disimpulkan bahwa kejadian hirsutisme jarang ditemui. Dari hasil penelitian SOPK dengan IR (+) tidak ditemukan kejadian hirsutisme. Sementara itu, pada kelompok SOPK dengan IR (-) terdapat 1 orang $(1,42 \%)$ yang memiliki gambaran klinis hirsutisme. Berdasarkan hasil uji statistik fisher exact test ditemukan $\mathrm{p}$ value 0,667 . Hal ini dapat disimpulkan bahwa tidak terdapat hubungan yang bermakna antara hirsutisme dengan resistensi insulin.

Hubungan resistensi insulin dengan acne juga dapat dilihat pada tabel 6 . Dari hasil penelitian acne ditemukan sebanyak 7 orang $(20 \%)$ pada kelompok SOPK dengan IR (+), dan 14 orang (20\%) pada kelompok SOPK dengan IR (-). Dari hasil uji statistik chi square disimpulkan bahwa tidak ada hubungan yang bermakna antara acne dengan resistensi insulin pada sindrom ovarium polikistik, dengan $p=1,00$.

\section{PEMBAHASAN}

\section{Resistensi Insulin pada Sindrom Ovarium Polikistik}

Pada Gambar 1 dapat dilihat bahwa dari hasil penelitian 105 data SOPK ditemukan 33,33\% atau 35 orang mengalami resistensi insulin. Hal ini sedikit berbeda dengan penelitian sebelumnya, Rusnasari dalam penelitiannya di RSIA Anugerah Semarang pada tahun 2005 menyimpulkan bahwa $82,9 \%$ pasien SOPK mengalami resistensi insulin. ${ }^{8}$ Selain itu, hasil penelitian di RS. Dr. Cipto Mangunkusumo Jakarta didapatkan $75 \%$ pasien SOPK yang menderita resistensi insulin. ${ }^{7}$

Resistensi insulin diyakini sebagai principal underlying etiologic factor. ${ }^{10}$ Resistensi insulin akan menimbulkan keadaan hiperinsulinemia sebagai reaksi kompensasi insensitivitas insulin. Tingginya kadar insulin merangsang berbagai produksi androgen ovarium dengan berbagai mekanisme, yaitu penurunan kadar IGFBP-I, peningkatan IGF-I, aktivasi jalur autofosforilasi serin, peningkatan aktivasi P450c17, dan penurunan kadar SHBG. Mekanisme-mekanisme tersebut akan menstimulasi sintesis androgen sehingga kadar androgen menjadi tinggi. Tingginya kadar androgen akan mengganggu sistem aromatase sehingga memicu terjadinya atresia folikel lebih dini dan menimbulkan berbagai gambaran klinis SOPK. ${ }^{3-5}$

Dibanding dengan penelitian sebelumnya, terdapat perbedaan hasil resistensi insulin pada SOPK. Perbedaan ini kemungkinan bisa disebabkan karena resistensi insulin bukan satusatunya etiologi SOPK. Selain itu perbedaan ini juga bisa dikaitkan dengan jumlah responden penelitian, dan banyaknya subjek penelitian yang didiagnosa SOPK tetapi tidak memeriksa kadar gula darah dan insulin sehingga tidak memenuhi kriteria inklusi dan eksklusi.

\section{Hubungan Resistensi Insulin dengan Infertilitas}

Berdasarkan hasil penelitian dapat dilihat 
bahwa sebagian besar penderita SOPK mengalami masalah infertilitas, yaitu sebesar 72,04\% (67 orang). Hal ini sejalan dengan penelitian yang dilakukan oleh Wiweko dan Mulya yang menyimpulkan bahwa $61 \%$ responden SOPK mengalami infertilitas. ${ }^{7}$ Penelitian Rusnasari juga memperkuat hasil penelitian dimana 100\% responden penelitian mengalami infertilitas yang terdiri dari: $91,4 \%$ infertilitas primer dan 8,6\% infertilitas sekunder. ${ }^{8}$

Jika dilihat berdasarkan resistensi insulin, sebagian besar subjek penelitian dengan IR (+) memiliki angka kejadian infertilitas yang tinggi, yaitu sebesar 71,9\% (23 orang) dari 35 pasien SOPK. Hal ini sejalan dengan penelitian yang dilakukan oleh Refaie, dkk yang mendapatkan bahwa dari 55 pasien SOPK dengan resistensi insulin yang diteliti 34 orang atau $62 \%$ diantaranya mengalami masalah infertilitas. ${ }^{11}$

Hasil uji analisis dengan menggunakan uji chi-square didapatkan nilai $p$ sebesar 1,00 ( $p$ > 0,05). Hal ini menunjukkan bahwa tidak ada hubungan yang bermakna antara resistensi insulin dengan infertilitas pada pasien sindrom ovarium polikistik. Penelitian ini juga sejalan dengan penelitian yang dilakukan oleh Refaie et al, dimana hasil penelitiannya menunjukkan tidak ada hubungan yang bermakna antara gravid dan paritas dengan resistensi insulin pada wanita SOPK dengan infertilitas $(p=1,00$ dan 0,42$){ }^{11}$

Resistensi insulin mempengaruhi siklus ovulatorik wanita usia reproduksi. Resistensi insulin menyebabkan tingginya kadar insulin didalam darah (hiperinsulinemia). Makin tinggi kadar insulin seorang wanita, maka siklus menstruasi juga semakin jarang. Hal ini terkait dengan tingginya kadar androgen akibat hiperinsulinemia. Tingginya kadar androgen akan menghambat aromatisasi dan kerja FSH yang berdampak pada ketidakmatangan folikel sehingga estrogen yang dihasilkan berkurang. Jika kadar estrogen berkurang maka tidak terjadi umpan balik positif pada LH yang menyebabkan tidak terjadinya lonjakan LH dan ovulasipun tidak terjadi. ${ }^{4}$
Pada awalnya, gangguan ovulasi ini bermanifestasi klinis menjadi oligomenore dan amenore. Jika keadaan siklus anovulatorik ini berlanjut maka akan timbul infertilitas. ${ }^{12}$

Penelitian ini menunjukkan bahwa tidak ada hubungan resistensi insulin dengan infertilitas pada wanita dengan sindrom ovarium polikistik. Hal ini berbeda dengan teori yang dikemukakan. Perbedaan ini kemungkinan disebabkan karena infertilitas yang terjadi akibat gangguan siklus anovulatorik tidak hanya dipengaruhi oleh resistensi insulin.

\section{Hubungan Resistensi Insulin dengan Obesitas}

Pada Tabel 3 dapat disimpulkan bahwa dari 105 data SOPK yang diteliti 50,5\% (53 orang). Hal ini sesuai dengan penelitian yang dilakukan oleh Wiweko dan Mulya pada tahun 2007 di RS. Dr. Cipto Mangunkusumo Jakarta yang menemukan $73 \%$ kasus obesitas pada penderita SOPK. ${ }^{7}$

Pada SOPK dengan resistensi insulin ditemukan $77,14 \%$ (27 orang) dari 35 orang yang mengalami gejala klinis obesitas. Hal ini sejalan dengan penelitian Wiweko dan Mulya dengan hasil $84 \%$ pasien SOPK dengan resistensi insulin yang mengalami obesitas. ${ }^{7}$

Hasil uji analisis chi-square diperoleh nilai 0,000 , artinya terdapat hubungan bermakna antara resistensi insulin dengan obesitas pada wanita dengan sindrom ovarium polikistik. Refaie dkk dalam penelitiannya juga memperoleh hasil yang hampir sama, dimana pada penelitian tersebut didapatkan $p=0,03 \%$. Penelitian tersebut menunjukkan bahwa ditemukan hubungan yang bermakna antara resistensi insulin dengan obesitas pada wanita dengan sindrom ovarium polikistik. ${ }^{13}$

Obesitas dapat memicu terjadinya sindrom ovarium polikistik. Hal ini terjadi karena obesitas dapat menimbulkan resistensi insulin melalui peningkatan produksi asam lemak bebas. Akibatnya terjadi penurunan sensitivitas insulin sehingga terjadi hiperinsulinemia. ${ }^{5}$ Tingginya kadar insulin yang terkait dengan resistensi insulin dapat menstimulasi ovarium untuk menghasilkan kadar 
androgen yang berlebihan. ${ }^{13}$ Obesitas juga akan meningkatkan kadar kolesterol dan menstimulasi jalur steroid yang akan mengubah kolesterol menjadi androstenedion. Setelah itu, androstenedion akan dikoversi menjadi estrogen. Tingginya kadar androgen dapat mengakibatkan terganggunya proses konversi androstenedion. Akibatnya kadar androgen menjadi semakin tinggi dan menimbulkan sindrom ovarium polikistik. ${ }^{4,5}$

\section{Hubungan Resistensi Insulin dengan Hirsutisme}

Hasil penelitian mengenai hirsutisme pada wanita dengan SOPK didapatkan 1 orang $(0,95 \%)$ dari 105 data subjek penelitian dengan SOPK. Hal ini berbeda dengan penelitian Wiweko dan Mulya yang mendapatkan $18 \%$ kasus hirsutisme dengan SOPK. ${ }^{7}$ Rusnasari dalam penelitiannya juga mendapatkan $77,1 \%$ kejadian hirsutisme pada SOPK. ${ }^{8}$

Pada hasil penelitian SOPK dengan resistensi insulin, tidak ditemukan kejadian hirsutisme. Hal ini berbeda dengan penelitian yang dilakukan oleh Refaie et al yang menemukan 67,6\% kasus hirsutisme pada wanita SOPK dengan resistensi insulin. ${ }^{11}$

Hasil uji analisis dengan menggunakan fisher probability exact test / uji exact fisher tidak ditemukan hubungan yang bermakna antara resistensi insulin dengan hirsusutime pada sindrom ovarium polikistik dengan $p=0,667$. Hal ini berbeda dengan penelitian Refaie et al yang mendapatkan $\mathrm{p}=0,03 \%$, yang artinya terdapat hubungan bermakna antara resistensi insulin dengan hirsutisme pada SOPK. ${ }^{11}$

Pada SOPK, resistensi insulin juga berpengaruh terhadap timbulnya hirsutisme. Hal ini terkait dengan tingginya kadar androgen akibat hiperinsulinemia pada wanita SOPK dengan resistensi insulin seperti yang telah dijelaskan sebelumnya. Peningkatan androgen tersebut akan berperan penting dalam menentukan jenis dan distribusi rambut. Androgen akan diubah menjadi Dehydrotestosteon (DHT) yang akan mengkonversi rambut vellus halus menjadi rambut terminal kasar. Konversi ini bersifat ireversibel dan hanya rambut yang berada dalam area sensitif yang dapat diubah menjadi rambut terminal, seperti bibir atas, dagu, jambang, dada, aksilla, dan linea alba di perut bagian bawah. ${ }^{12}$

Berdasarkan kepustakaan dan penelitian sebelumnya ditemukan perbedaan hasil antara hubungan resistensi insulin dan hirsutisme pada wanita dengan sindrom ovarium polikistik. Hal ini mungkin dipengaruhi oleh perbedaan genetik terhadap jumlah reseptor androgen pada folikel rambut dan senstivitas terhadap androgen. Selain itu, faktor ras juga mempengaruhi munculnya gejala hirsutisme tersebut. ${ }^{7,14,15}$ Sebagai contoh, gejala hirsutisme lebih sering ditemukan pada bangsa mediterania yang secara genetik memang memiliki pertumbuhan rambut di tubuh yang berlebihan dibandingkan orang-orang Asia. ${ }^{14}$

\section{Hubungan Resistensi Insulin dengan Acne}

Pada Tabel 3 didapatkan hasil penelitian 20\% (21 orang) kejadian acne dari 105 data pada sindrom ovarium polikistik. Hal ini sejalan dengan studi yang dilakukan Franks yang melaporkan 27\% kasus acne pada SOPK. ${ }^{4}$ Sementara itu, hasil penelitian yang dilakukan oleh Rusnasari dri RSIA Anugerah Semarang ditemukan 26 orang (74,3\%) dari 35 responden dengan acne pada wanita dengan SOPK. ${ }^{8}$

Pada kelompok SOPK dengan resistensi insulin, ditemukan $20 \%$ atau 7 orang dari 35 orang kasus acne. Hal ini sejalan dengan penelitian yang dilakukan oleh Mandrelle et al yang mendapatkan $8,8 \%$ kasus acne pada wanita SOPK dengan gangguan sindrom metabolik. ${ }^{16}$

Pada hasil uji analisis dengan menggunakan chi-square tidak ditemukan adanya hubungan yang bermakna antara resistensi insulin dengan acne pada sindrom ovarium polikistik dengan hasi $\mathrm{p}=$ 1,00. Hasil uji tersebut sejalan dengan Mandrelle et al yang juga melakukan uji chi-square pada wanita SOPK dengan atau tanpa gangguan sindrom metabolik. Pada penelitian tersebut didapatkan nilai $p=0,935$, yang artinya tidak ditemukan hubungan bermakna antara acne dengan atau tanpa gangguan sindrom metabolik pada wanita SOPK. ${ }^{16}$ 
Sama halnya dengan hirsutisme, timbulnya gambaran klinis acne pada penderita dengan sindrom ovarium polikistik terkait dengan tingginya kadar androgen. Hal tersebut terjadi karena androgen yang berlebihan di pilosebaceous unit (PSU) akan menstimulasi terbentuknya sebum yang berlebihan. Akibatnya terjadi gangguan drainase dan membentuk komedo dan menimbulkan peradangan akibat invasi dari kolonisasi abnormal microba (Proprionibacterium acnes). ${ }^{4}$

Berdasarkan hasil penelitian ditemukan hubungan yang tidak bermakna antara resistensi insulin dengan acne pada SOPK. Hal ini juga diperkuat dengan penelitian sebelumnya yang juga menemukan hasil yang sama. Hal ini berbeda dengan teori yang dikemukakan. Sama halnya dengan hirsutisme, munculnya gejala klinis acne juga dipengaruhi oleh perbedaan reseptor androgen di pilosebaceous unit (PSU) dalam merespon sirkulasi hormon androgen tersebut. ${ }^{7,17}$

\section{KESIMPULAN}

Terdapat resistensi insulin berdasarkan HOMA-IR pada sindrom ovarium polikistik.

Gambaran klinis pada sindrom ovarium polikistik adalah amenore/oligomenore, infertilitas, obesitas, hirsustisme, dan acne.

Ada hubungan yang bermakna antara resistensi insulin dengan obesitas pada sindrom ovarium polikistik, dan tidak ada hubungan yang bermakna antara resistensi insulin dengan infertilitas, hirsustisme, dan acne pada sindrom ovarium polikistik.

\section{UCAPAN TERIMA KASIH}

Terima kasih kepada Dr. dr. H. Eva Decroli, SpPD-KEMD,FINASIM dan dr. Hj. Putri Sri Lasmini, SpOG $(K)$ atas bimbingan, bantuan, dan motivasi dalam melakukan penelitian ini. Terima kasih kepada staf Apotek Sinar Padang atas bantuannya dalam penelitian ini.

\section{DAFTAR PUSTAKA}

1. Norman JR, Ruijin Wuu, Marcin T, Stankiewicz. Polycystic ovary syndrome. MJA Practice Essentials. 2004;180:132-7.

2. Zaccur HA. Epidemiology, clinical manifestation, and pathophysiology of polycistic ovarium syndrom. Advances Student in Medicines.2003;3:S733-S8.

3. Dunaif A. Insulin resistance and the polycystic ovary syndrome: mechanism and implications for pathogenesis. Endocrine Review. 1997;18(6):774-800.

4. Balen HA, Gerrard SC, Roy H, Richard SL. Polycystic ovary syndrome: a guide to clinical management. Taylor \& Francis; 2005.

5. Speroff L, Marca AF. Clinical gynecologic endocrinology and Infertility. Edisi ke-8. Baltimore, USA: William Lippincot William and Wilkins; 2011.

6. Hopkinson ZEC, Naveed Sa, Flamming R, Ian A Greer. Polycystic Ovarian Syndrome: The Metabolic Syndrome Comes to Gynecology. BMJ.1998;317;329-32.

7. Wiweko B, Mulya R. Profil resistensi insulin pada pasien sindrom ovarium polikistik (SOPK). Majalah Obstetri Ginekologi Indonesia. 2008;32(2):93-8.

8. Rusnasari, Veronica D. hubungan resistensi insulin (HOMA-IR) dengan obesitas dan perubahan hormon androgen pada penderita sindrom ovarium polikistik (tesis). Semarang: Fakultas Kedokteran Universitas Dipenogoro; 2005.

9. Gardner, David G, Shoback D. Greenspan's Basic \& clinical endocrinology Edisi ke-8. USA: Mc Graw Hill Medical.2004; 527-32.

10. Kiess, Wieland, Claude Marcus, Martin Wabitsch. Obesity in childhood and adolesence. Switzerland: Karger.2004; 54.

11. Refaie Ashraf MN, Gehan AK Ibrahim, Saad Al Oash. Characteristic of polycystic ovary 
syndrome with and without insulin resistance and the role of insulin sensitizing drug (metformin) and in its management. Midle East Fertility Society Journal.2005;10(2):142-9.

12.Schorge, Schaffer, Halvorson, Hoffman, Bradshaw, Cunningham. Williams gynecology. USA: The McGraw-Hills Companies Inc.2008; 383-99.

13. Pfeifer, Samantha M., Sari Kives. Polycystic ovary syndrome in the adolescent. Obstet Gynecol Clin N Am 36. 2009;129 -52.

14. Eden, John. Polycystic ovary syndrome : a woman's guide to identifying and managing PCOS. Australia: National Library of Australia; 2005.

15. Isselbacher, Braunwald, Wilson, Martin, Fauci,
Kasper. Harrison prinsip - prinsip ilmu penyakit dalam (Ahmad H. Asdie ed) Volume I. Jakarta: EGC.1999;309-10.

16. Mandrelle, Kavita, Mohan S. Kamath, Dian J. Bondu, Achamma Chandi, Alleyamma TIK, Korulla George. Prevalence of metabolic syndrome in women with polycystic ovary syndrome attending an infertility clinic in tertiary care hospital in South India. Journal Human of Reproductive Science.2012;5 (issue 1):26-31.

17. Pangastuti, Niken $P$, Kanadi Sumapradja. Profile of polycystic ovary syndrome patients Dr. Cipto Mangunkusumo general hospital Jakarta March 2009 - April 2010. Indonesia J Obstet Gynecol. 2011;35(1): 8-13. 